\title{
Pengaruh Penguasaan Ragam Bahasa Kritik dan Kalimat Efektif terhadap Pembelajaran Menulis Teks Resensi
}

\author{
Firdaus \\ Fakultas Pascasarjana, Universitas Indraprasta PGRI \\ Jalan Nangka No. 58 C/TB. Simatupang, Tanjung Barat, \\ Jakarta Selatan 12530 \\ firdausbekasi@yahoo.co.id
}

\begin{abstract}
The purpose of this study is to determine 1) the influence of mastery of the language variety of criticism and mastery of effective sentences on learning writing text students. Private SMK in Bekasi city. 2) The effect of a variety Of language mastery criticism of the study write text reviews private vocational students in Bekasi. 3) Effect of mastery effective sentence to learning to write text reviews private vocational student in Bekasi. The method used in this research is survey method with correlation and regression analysis, by linking learning reviewer. Data on variables mastery of language diversity criticism and mastery effective sentence with data showing text writing learning reviewer. Data on the teaching of writing text reviews obtained through a direct test by asking the respondent to make a shaped article recent books that have been determined by researchers. From the results of the analysis of research data obtained the conclusion that 1) There is a significant influence mastery of the variety of criticisms and effective sentences of learning to write text recent of private SMK students in the city of Bekasi. this is proved by $\mathrm{Sig}=0.000<0,05$ and Fcount $=49,431 ;(2)$ there is a significant influence mastery of the variety of language criticism of learning writing text students private SMK students in the city of Bekasi, this is proved by the value of Sig $=0.002<0,05$ and tcount $=$ 2,901; and (3) there is a significant influence of effective sentence mastery of learning text writing student SMK in Bekasi City, this is proved by Sig $=0.000<0,05$ and tcount $=4,877$.
\end{abstract}

Keywords: Variety of critical languages, effective sentences, learning to write a review text

\begin{abstract}
Abstrak
Tujuan penelitian ini adalah untuk mengetahui 1) pengaruh penguasaan berbagai bahasa kritik dan penguasaan kalimat efektif terhadap pembelajaran menulis teks siswa. SMK Swasta di kota Bekasi. 2) Pengaruh berbagai kritik penguasaan bahasa of studi menulis teks ulasan siswa SMK swasta di Bekasi. 3) Pengaruh penguasaan kalimat efektif terhadap pembelajaran menulis teks ulasan siswa SMK swasta di Bekasi. Metode yang digunakan dalam penelitian ini adalah metode survei dengan analisis korelasi dan regresi, dengan menghubungkan pengkaji pembelajaran. Data pada variabel penguasaan bahasa keragaman kritik dan penguasaan kalimat efektif dengan data yang menunjukkan pembelajaran menulis teks resensi. Data tentang pengajaran menulis ulasan teks diperoleh melalui tes langsung dengan meminta responden untuk membuat artikel berbentuk buku-buku terbaru yang telah ditentukan oleh peneliti. Dari hasil analisis data penelitian diperoleh kesimpulan bahwa 1) Ada pengaruh yang signifikan penguasaan terhadap berbagai kritik dan kalimat efektif pembelajaran menulis teks terbaru dari siswa SMK swasta di Kota Bekasi. ini dibuktikan oleh Sig $=0,000<0,05$ dan Fcount $=49,431$; (2) ada pengaruh yang signifikan penguasaan terhadap berbagai kritik bahasa terhadap pembelajaran menulis teks siswa siswa SMK swasta di Kota Bekasi, hal ini dibuktikan dengan nilai Sig $=0,002<0,05$ dan thitung $=2,901$; dan (3) ada pengaruh yang signifikan penguasaan kalimat efektif terhadap pembelajaran menulis teks siswa SMK di Kota Bekasi, hal ini dibuktikan dengan Sig $=0,000<0,05$ dan thitung $=4,877$.
\end{abstract}

Kata Kunci: Ragam bahasa kritik, kalimat efektif, pembelajaran menulis teks resensi

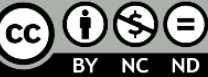




\section{PENDAHULUAN}

Bahasa dapat menjadi unsur utama yang mempengaruhi kenyataan yang terjadi di masyarakat. Bahasa tidak hanya sebagai ujaran atau tulisan yang memiliki struktur, arti leksikal dan gramatikal saja, tetapi juga memiliki makna ideologi yang dibangun pemakainya di balik kata-kata yang terdapat dalam bahasa tersebut. Melalui bahasa, seseorang, kelompok atau peristiwa dapat ditampilkan dan dimaknai berbeda dari kenyataan yang sebenarnya. Hal ini membuat masyarakat perlu memahami bahwa sebuah berita atau informasi yang muncul ditentukan oleh pengguna bahasa yang mempunyai tujuan agar berita dapat dianggap benar.

Keberadaan bahasa dalam berbagai media tidak hanya sebagai alat untuk menggambarkan keadaan yang sebenarnya terjadi, tetapi juga turut menentukan arti dari sebuah keadaan. Setiap persoalan dapat dimunculkan berbeda oleh media.Bahasa media sebagai sumber informasi memiliki kecenderungan membangun opini yang berkembang di masyarakat yang bersifat subjektif.Informasi yang diberitakan media belum tentu sesuai atau berdasarkan realita sebenarnya. Oleh karena itu, masyarakat perlu mengkritisi berita atau informasi yang tersebar sebelum meyakini kebenarannya.

Berpikir kritis sangat penting dalam kehidupan sehari-hari. Mengingat banyak sekali fenomena dalam kehidupan sehari-hari yang perlu dikritisi. Kemampuan berpikir kritis dapat mengembangkan kemampuan berpikir lainnya, seperti kemampuan untuk membuat keputusan dan menyelesaikan masalah. Berpikir dan bersikap kritis tersebut merupakan analisis kritis terhadap sesuatu hal atau keadaan sosial dan politik yang berkembang di masyarakat. Oleh karena itu, penting bagi siswa untuk menguasai kompetensi berpikir kritis. Analisis kritis atau pemikiran kritis siswa dapat membuat mereka dapat mencermati dan menyeleksi dahulu mana pernyataan atau informasi yang benar ataupun tidak, apakah media menawarkan pesan yang sehat atau tidak.

Berpikir kritis pada tataran filosofis dipandang sebagai keterampilan yang memiliki nilai kritikal yang artinya sesuatu yang dianggap baik. Oleh karena itu, mengembangkan berpikir kritis dalam pembelajaran berarti memberikan penghargaan kepada siswa sebagai pribadi dan mempersiapkan siswa untuk kehidupan kedewasaannya dengan mengikutsertakan mereka di dalam pemenuhan perkembangan dirinya sendiri dan arah dari perkembangannya sendiri (Tilaar, 2011, hlm. 17). Berpikir kritis yang dilakukan siswa merupakan bentuk kesadaran sebagai makhluk yang aktif. Mereka bertindak bukan atas dasar insting, melainkan berpikir kritis dalam mengkaji berbagai alternatif perbuatan yang memiliki tujuan. Tindakan atau perbuatan tersebut membuat mereka dapat berkomunikasi dengan sesama dan bekerja untuk memperbaiki taraf kehidupannya (Tilaar, 2012a, hlm. 127).

Keterampilan berpikir kritis penting dikuasai siswa.Zamroni dan Mahfudz (2009, hlm. 23-29) menjelaskan beberapa alasan yang mendasari pentingnya berpikir kritis.Pertama, perkembangan ilmu pengetahuan dan teknologi yang begitu pesat menyebabkan sumber dan esensi informasi yang diterima siswa sangat beragam. Oleh karena itu, siswa dituntut memiliki kemampuan memilih dan memilah informasi yang baik dan benar untuk memperkaya khazanah 
pemikirannya. Kedua, siswa merupakan salah satu sumber daya yang memiliki kekuatan tinggi. Oleh karena itu, agar kekuatan itu dapat terarah dan memiliki komitmen yang tinggi terhadap moral, maka mereka perlu dibekali dengan kemampuan berpikir yang memadai (deduktif, induktif, reflektif, kritis dan kreatif) agar kelak mampu berkiprah dalam mengembangkan bidang ilmu yang ditekuninya. Ketiga, siswa adalah warga masyarakat yang saat ini maupun nanti akan menjalani kehidupan yang semakin kompleks. Hal ini menuntut mereka memiliki keterampilan berpikir kritis dan kemampuan untuk memecahkan masalah yang dihadapinya secara kritis. Keempat, berpikir kritis adalah kunci menuju berkembangnya kreativitas karena fenomena atau permasalahan yang ada akan menuntut siswa untuk berpikir kreatif. Kelima, banyak lapangan pekerjaan yang membutuhkan keterampilan berpikir kritis, maka berpikir kritis adalah kunci keberhasilannya. Keenam, setiap saat siswa selalu dihadapkan pada pengambilan keputusan yang akan memerlukan keterampilan untuk berpikir kritis.

Untuk mengatasi kondisi krisis seperti ini diperlukan penelitian dan pengembangan keterampilan-keterampilan berpikir kritis. Ketiga, adanya perbedaan pengetahuan masyarakat. Sejauh ini masyarakat di bawah usia 25 tahun sudah bisa mengonlinekan berita yang mereka tulis. Proses berpikir kritis akan melahirkan pemikiran kritis yang tercermin dalam kegiatan kritik atau mengkritik. Kegiatan mengkritik sudah sejak lama dilakukan oleh manusia dari berbagai kalangan. Dalam kehidupan sehari-hari, disadari ataupun tidak, manusia sering menggunakan kata, kalimat atau bahasa yang berisi tanggapan, komentar, atau penilaian terhadap suatu karya. Hal ini karena manusia memiliki kemampuan kreatif, yaitu kemampuan mengimajinasikan, menafsirkan dan mengemukakan gagasan. Kemampuan tersebut mendorong manusia untuk melakukan kritik.Kritik terhadap berbagai karya merupakan dorongan sikap dan berpikir kritis yang didasari unsur karsa, cipta dan rasa dalam diri manusia. Kualitas dan kuantitas kritik akan tampil berbeda. Hal ini disebabkan oleh usia, jenis kelamin, pengalaman, pendidikan, dan upaya pengembangannya.

Penilaian terhadap sebuah karya haruslah objektif atau berdasarkan faktafakta dan tidak memihak. Pengungkapan kritik terhadap kelemahan dan keunggulan sebuah karya sebaiknya tidak berlebihan. Kritik terhadap keunggulan karya hendaknya sesuai dengan data atau fakta empiris tanpa mengabaikan atau menutupi kekurangannya. Kritik terhadap kelemahan sebuah karya sebaiknya bersifat membangun dan tidak menjatuhkan. Penyampaian kritik tidak hanya harus objektif, tetapi hendaknya juga menggunakan bahasa yang santun dan efektif.Selain itu, kritik perlu juga disertai dengan saran atau alternatif pemecahannya. Selain itu, siswa dapat belajar menghargai dan menerima penilaian atau kritikan orang lain. Berbagai bentuk kegiatan mengkritik perubahan sosial dan politik yang terjadi sudah tentu menggunakan bahasa sebagai medianya. Fenomena pemakaian bahasa yang dikontrol oleh faktor-faktor yang bersifat sosial dan situasional tersebut menyebabkan keragaman bahasa (Wijana, 2013, hlm. 2-6). Keragaman bahasa terus menerus berkembang seiring meluasnya pemakaian bahasa di tengah-tengah masyarakat. Hal ini yang membuat munculnya ragam bahasa politik, bahasa jurnalistik, bahasa kritik, dan lain-lain. 
Namun dewasa ini, kritik masih cenderung dianggap sebagai perkatan yang tajam, menjatuhkan, dan membuat ketersinggungan, sehingga tidak semua orang mudah menerima kritik. Selain itu, kritik pun dilakukan dengan bahasa yang kurang santun dan kurang efektif. Kenyataan tersebut akan memberikan pembelajaran yang kurang baik bagi para siswa sebagai generasi muda.

Bahasa memiliki fungsi sebagai alat komunikasi, alat mengekspresikan diri, alat berintegrasi dan beradaptasi sosial, alat kontrol sosial, dan alat berpikir (Finoza, 2005, hlm. 2). Oleh karena itu, untuk dapat melakukan kegiatan berpikir ilmiah dengan baik maka diperlukan sarana berupa bahasa, logika, matematika, dan statistika. Kemampuan berpikir ilmiah yang baik harus didukung pula oleh penguasaan sarana bepikir tersebut dengan baik (Suriasumantri, 2007, hlm. 167). Bila bahasa diyakini sebagai alat dalam proses berpikir dan alat untuk menyampaikan pikirannya kepada orang lain, maka pendidikan bahasa seharusnya dapat meningkatkan kemampuan berpikir kritis.

Mengkritik atau meresensi buku merupakan salah satu kompetensi dasar yang harus dikuasai siswa. Hal ini terdapat dalam kurikulum KTSP mata pelajaran bahasa Indonesia kelas IX semester 2 yang menjelaskan bahwa kompetensi dasar 4.2 yaitu meresensi buku pengetahuan. Kompetensi ini juga tercantum dalam kurikulum 2013 mata pelajaran bahasa Indonesia kelas XI yaitu kompetensi keterampilan menulis teks ulasan buku.

Teks resensi atau teks ulasan buku digunakan untuk menyampaikan penilaian atau evaluasi mengenai buku kepada khalayak dengan tujuan untuk menyajikan kelayakan atau kualitas buku. Sebagai suatu jenis teks, resensi buku memiliki ciri mengulas keunggulan dan kelemahan buku. Menurut Samad (1997, hlm. 3) meresensi buku berarti menilai buku.Menilai berarti mengulas, mempertimbangkan, mengkritik, dan menunjukkan kelebihan dan kekurangan buku dengan penuh tanggung jawab.Tanggung jawab di sini berarti menyampaikan argumen, kesimpulan, dan data yang meyakinkan. Dengan demikian, dalam teks resensi buku terdapat ragam bahasa kritik karena meresensi buku sama halnya dengan mengkritik buku.

Analisis teks sebagai kajian bahasa yang didasarkan pada pendekatan pragmatik berarti mengkaji teks bahasa dalam pemakaiannya. Brown dan Yule (dalam Ahmad HP, 2012, hlm. 132) menyatakan bahwa analisis teks berusaha menganalisis bahasa dalam penggunaannya sebagai alat untuk berkomunikasi. Oleh karena itu, analisis tersebut tidak terbatas pada bentuk-bentuk bahasa yang terpisah dari maksud dan fungsi bahasa, melainkan menghubungkan bentukbentuk tersebut dengan penggunaannya dalam berkomunikasi yang dipengaruhi hal-hal di luar kebahasaan.

Kajian bahasa tidak hanya memusatkan perhatian pada struktur kebahasaan saja, tetapi juga pada fenomena penggunaan bahasa yang dinamis. Kajian kebahasaan sudah memasuki proses-proses komunikatif dan sosial budaya. Sebagaimana Koentjaraningrat (dalam Chaer dan Leonie, 1995) yang mengatakan bahwa bahasa merupakan bagian dari kebudayaan. Dengan demikian, bahasa memiliki peranan dalam perkembangan budaya dan peradaban suatu bangsa.Kajian kebahasaan tidak semata-mata membahas gramatikal bahasa. Namun, kajian bahasa mengarah kepada sikap kritis, yaitu pada tuturan dan 
tulisan aktual dalam komunikasi di masyarakat.Hal ini terwujud di dalam bahasa kritik.

Bahasa kritik termasuk bahasa yang memiliki fungsi direktif dan fungsi referensial karena bahasa kritik berupaya menyediakan informasi bagi pembaca melalui keterangan atau interpretasi yang terkandung dalam sebuah teks. Informasi atau keterangan tersebut berupa hasil analisis atau evaluasi tentang sesuatu hal. Evaluasi atau penilaian tentang kelebihan dan kekurangan sesuatu hal dapat membuat orang lain bertindak atau melakukan sesuatu. Bahasa kritik membahas fungsi bahasa secara lebih luas dan dinamis dalam konteks-konteks historis, sosial, dan retoris. Bahasa kritik menurut Crystal (dalam Santoso, 2012, hlm. 101) bertujuan mengungkap relasi kuasa tersembunyi dan proses-proses ideologis yang muncul dalam teks-teks lisan atau tulis.

Bahasa kritik dalam teks dipahami sebagai tulisan yang berisi penilaian atau timbangan. Teks ini mengandung kritik atau penilaian suatu karya atau produk yang dilihat, dibaca atau dinikmati. Penilaian tersebut merupakan hasil keputusan dari berpikir kritis dan aktualisasi dari kegiatan mengkritik. Mengkritik dapat diartikan sebagai kegiatan mengemukakan pendapat atau tanggapan terhadap suatu karya yang disertai dengan uraian dan pertimbangan baik buruknya sesuatu hal. Mengkritik cenderung dikaitkan dengan kegiatan mencela kekurangan sebuah karya. Padahal mengkritik pun merupakan kegiatan mengemukakan pendapat terhadap sesuatu karya yang dianggap bernilai positif dan memuji kelebihannya.

Pemakaian bahasa secara santun belum banyak mendapat perhatian. Sering ditemukan pemakaian bahasa yang baik ragam bahasanya dan benar tata bahasanya, tetapi nilai rasa yang terkandung di dalamnya menyakitkan hati pembaca atau pendengarnya. Hal ini terjadi karena pemakai bahasa belum mengetahui bahwa di dalam suatu struktur bahasa terdapat struktur kesantunan. Struktur bahasa yang santun adalah struktur bahasa yang disusun oleh penulis atau penutur agar tidak menyinggung perasaan pembaca atau penengar (Pranowo, 2012, hlm. 4)

Bahasa kritik sebaiknya disampaikan secara santun dan menggunakan kalimat yang efektif. Strategi penggunaan bahasa kritik yang santun dan efektif perlu dikuasai oleh siswa. Kesantunan menunjukkan kehalusan budi bahasa. Kalimat yang efektif yaitu kalimat yang benar dan jelas akan dengan mudah dipahami orang lain dan dapat memberi informasi kepada pembaca secara tepat. Pilihan kata dalam kalimat yang digunakan dalam bahasa kritik membuat bahasa kritik terlihat santun atau tidak. Kesantunan berbahasa menunjukkan citra diri pemakainya menjadi baik. Bahasa kritik yang dikaji dalam tulisan siswa berupa resensi buku ini diharapkan dapat memberikan kontribusi positif pada pembelajaran mengkritik atau meresensi buku. Pembelajaran mengkritik atau meresensi buku menjadi lebih menarik dengan penggunaan bahan pembelajaran yang variatif, konkret, dan kontekstual. Bahan pembelajaran yang sesuai memiliki kriteria di antaranya bermanfaat, menarik, dan mencapai tujuan pembelajaran. Selanjutnya, harapan peneliti hasil analisis data penelitian ini dapat diaplikasikan dalam pembelajaran teks resensi dan bermanfaat untuk perkembangan bahasa. 


\section{METODE}

Penelitian dan pengisian kuesioner bagi siswa akan dilakukan di berbagai Sekolah Menengah Kejuruan (SMK) swasta di wilayah Kota Bekasi Provinsi Jawa Barat.

Metode penelitian yang digunakan adalah survei dengan teknik analisis data dan pembuktian hipotesis menggunakan analisis korelasi dan regresi linier sederhana. Variabel dalam penelitian ini terdiri dari satu variabel terikat, yaitu pembelajaran menulis teks resensi $(\mathrm{Y})$ dan dua variabel bebas, yaitu penguasaan ragam bahasa kritik $\left(\mathrm{X}_{1}\right)$ dan penguasaan kalimat efektif $\left(\mathrm{X}_{2}\right)$..

Populasi adalah keseluruhan dari objek penelitian dan populasi juga merupakan wilayah generalisasi berupa subjek atau objek yang menjadi kuantitatif atau karakteristik tertentu yang ditetapkan oleh peneliti untuk dipelajari dan kemudian diambil kesimpulan (Sugiyono dalam Ridwan 2004:54). Nawawi dalam Ridwan, (2004.54) menyebutkan bahwa "populasi adalah totalitas dari semua nilai yang mungkin, baik hasil menghitung atau pengukuran kuantitatif pada karakteristik tertentu mengenai sekumpulan obyek yang lengkap".

Populasi penelitian ini adalah seluruh siswa kelas XI SMK Swasta di wilayah Kota Bekasi tahun pelajaran 2017/2018, yang dibatasi pada siswa kelas XI SMK Taman Harapan Bekasi berjumlah 208 siswa, SMK Mandiri Bekasi berjumlah 224 siswa, dan SMK Catur Gelobal Bekasi berjumlah 171 siswa, dengan total keseluruhan 603 siswa tahun pelajaran 2017/2018.

Sedangkan sampel adalah sebagian dari populasi yang diteliti. Dengan kata lain, sampel merupakan sebagian atau bertindak sebagai perwakilan dari populasi sehingga hasil penelitian yang berhasil diperoleh dari sampel dapat digeneralisasikan pada populasi.

Sampel yang baik adalah sampel yang representatif, yaitu sampel yang dapat mewakili populasinya. Agar representatif, maka pengambilan sampel dari populasi harus menggunakan teknik pengambilan sampel (sampling) yang benar. Penarikan sampel diperlukan jika populasi yang diambil sangat besar, dan peneliti memiliki keterbatasan untuk menjangkau seluruh populasi maka peneliti perlu mendefinisikan populasi target dan populasi terjangkau baru kemudian menentukan jumlah sampel dan teknik sampling yang digunakan.

Arikunto (2004:54) mengatakan bahwa sampel adalah bagian dari populasiyang hendak diteliti dan mewakili populasi. Apabila jumlah populasi kurang dari 100 maka sampel bias diambil $10-15 \%$ atau $20-25 \%$ dari jumlah populasi atau lebih dengan memperhatikankondisi-kondisi yang terkait.

Berdasarkan hal di atas dank arena banyaknya anggota populasi dalam penelitian ini sebanyak 603 orang siswa, serta mengingat berbagai keterbatasan peneliti maka banyaknya anggota sampel dalam penelitian ini diambil 11,6\% dari populasi sebanyak 70 orang siswa. Selanjutnya teknik pemilihan sampel dalam penelitian ini menggunakan teknik gabungan antara teknik cluster, teknik proporsional dan teknik random. Teknik cluster digunakan untuk pengelompokan siswa menurut sekolah tempat belajar. teknik proporsional digunakan untuk menentukan jumlah/banyaknya anggota sampel dari setiap cluster/sekolah yang ada di populasi tersebut. Sedangkan teknik random digunakan untuk memilih anggota sampel dari setiap cluster/sekolah yang ada. 
Variabel Pembelajaran Menulis Teks Resensi Secara konseptual, pembelajaran menulis teks resensi yang dimaksud dalam penelitian ini adalah kemampuan untuk membuat tulisan atau wacana yang berbentuk paparan untuk menerangkan, menjelaskan, dan informasi mengenai objek tersebut sehingga dapat memperluas wawasan dan pengetahuan pembaca. Variabel Penguasaan Ragam Bahasa Kritik Secara operasional adalah total skor yang diperoleh responden atas jawaban yang diberikan berdasarkan soal tes untuk mengukur kemampuan untuk membuat atau menyusun ragam bahasa kritik yang efektif dan menjelaskannya. Variabel Penguasaan Kalimat Efektif adalah skor yang diperoleh responden dari jawaban yang diberikan atas butir-butir yang mengukur evaluasi diri terhadap penguasaan kalimat efektif yang dimilikinya. Adapun indikatorindikator untuk mengukur penguasaan kalimat efektif tersebut antara lain adalah : (1) penggunaan keefektifan kalimat yang sesuai dengan struktur kalimat, (2) penggunaan kata yang santun, dan (3) ketepatan penggunaan idiom dan majas.

Pengujian pengaruh penguasaan ragam bahasa kritik dan kalimat efektif terhadap pembelajaran menulis teks resensi dilakukan dengan menguji sejumlah hipotesis, yaitu hasil uji seperti pada Tabel 1. Instrumen penelitian untuk masingmasing variabel adalah kuesioner dengan soal pilihan ganda. Sebelum dipergunakan untuk pengumpulan data, kuesioner diujikan terlebih dahulu kepada siswa untuk melihat tingkat validitas dan reliabilitas instrumen. Setelah dipenuhi persyaratan normalitas dengan uji Kolmogorof-Smirnov, persyaratan homogenitas dengan uji Levene, persyaratan linieritas antar variabel, selanjutnya data dianalisis dengan teknik analisis jalur dengan bantuan program aplikasi SPSS.

\section{HASIL DAN PEMBAHASAN}

\section{Tabel 1. Rekapitulasi Hasil Perhitungan Pengujian Signifikasi Koefisien Regresi Pengaruh Variabel $X_{1}$ dan $X_{2}$ terhadap Variabel $Y$}

$\begin{array}{rlrrrrr}\text { Model } & & \text { Sum of } & \text { Df } & \text { Mean } & \text { F } & \text { Sig. } \\ & & \text { Squares } & & \text { Square } & & \\ & \text { Regression } & 2898.704 & 2 & 1449.352 & 49.431 & .000^{\mathrm{b}} \\ 1 & \text { Residual } & 1964.496 & 67 & 29.321 & & \\ & \text { Total } & 4863.200 & 69 & & & \end{array}$

a. Dependent Variable: Pembelajaran Menulis teks resensi

b. Predictors: (Constant), Penguasaan kalimat efektif, Penguasaan Ragam Bahasa Kritik

Hasil pengujian model penelitian telah memenuhi tiga kriteria yaitu: 1) Terdapat pengaruh yang signifikan penguasaan ragam bahasa kritik dan kalimat efektif secara bersama-sama terhadap pembelajaran menulis teks resensi siswa 
SMK Swasta Kota Bekasi. Hal ini dibuktikan dengan nilai Sig $=0.000<0,05$ dan Fhitung $=49,431.2$ ) Terdapat pengaruh yang signifikan penguasaan ragam bahasa kritik terhadap pembelajaran menulis teks resensi siswa SMK Swasta di Kota Bekasi. Hal ini dibuktikan dengan nilai Sig $=0.002<0,05$ dan thitung $=2$, 901. 3) Terdapat pengaruh yang signifikan penguasaan kalimat efektif terhadap pembelajaran menulis teks resensi siswa SMK Swasta di Kota Bekasi. Hal ini dibuktikan dengan nilai Sig $=0.000<0,05$ dan thitung $=4,877$

\section{Pengaruh penguasaan ragam bahasa kritik dan kalimat efektif secara bersama-sama terhadap pembelajaran menulis teks resensi.}

Dari deskripsi data setelah dilakukan analisis korelasi diperoleh koefisien korelasi sebesar 0,785 dan koefisien determinasi sebesar 61,6\%, setelah dilakukan pengujian dengan program SPSS terbukti bahwa koefisien korelasi tersebut signifikan. Hal ini berarti bahwa terdapat pengaruh variabel bebas penguasaan ragam bahasa kritik dan kalimat efektif secara bersama-sama terhadap variabel terikat terhadap pembelajaran menulis teks resensi.

sedangkan dari analisis regresi diperoleh persamaan garis regresi $\hat{\mathbf{Y}}=$ $32,575+0,238 \mathrm{X}_{1}+0,328 \mathrm{X}_{2}$ Nilai Konstanta $=32,575$ menunjukkan bahwa dengan penguasaan ragam bahasa kritik dan kalimat efektif paling rendah sulit bagi siswa tersebut untuk bisa mempunyai pembelajaran menulis teks resensi dengan baik, sedangkan nilai koefisien regresi sebesar 0,238 dan 0,328 menunjukkan bahwa terdapat pengaruh positif variabel bebas penguasaan ragam bahasa kritk dan penguasaan kalimat efektif secara bersama-sama terhadap variabel terikat pembelajaran menulis teks resensi. Angka koefisien regresitersebut juga menunjukkan bahwa setiap ada kenaikan satu nilai penguasaan ragam bahasa kritik maka terdapat kenaikan pembelajaran teks resensi terhadap tulisan siswa sebesar 0,238, dan setiap ada kenaikan satu nilai penguasaan kalimat efektif maka akan terdapat kenaikan terhadap pembelajaran menulis teks resensi sebesar 0,328.

Setelah dilakukan pengujian diperoleh bahwa niali $\operatorname{Sig}=0,000<0,05$ dan $\mathrm{F}_{\text {hitung }}=49,431$, maka $\mathrm{H}_{0}$ di tolak dan $\mathrm{H}_{1}$ diterima yang berarti bahwa koefisien regresi tersebut signifikan.

Menurut sintesis teori yang ada di Bab II, penguasaan ragam bahasa kritik adalah variasi bahasa yang terjadi karena pemakaian bahasa. Salah satu ragam bahasa berdasarkan pemakaiannya adalah ragam bahasa kritik. Dalam praktik pemakaian, para pemakai bahasa dapat menggunakan bahasa baik secara lisan maupun tulis. Dengan demikian, ragam bahasa kritik dalam praktiknya dapat dilakukan melalui lisan atau tulisan. Dalam penelitian ini, ragam bahasa kritik yang di analisis adalah ragam bahasa kritik yang disampaikan secara tertulis. Ragam bahasa kritik yang dipraktikkan secara tertulis ditandai dengan kelengkapan struktur dan pemakaian tanda baca. Pemakaian bahasa kritik tidak dapat dilepaskan dari kegiatan kritik atau mengeritik dan proses berpikir kritis.

Kritik merupakan salah satu jenis esai. Esai adalah suatu tulisan yang menggambarkan opini penulis tentang subyek tertentu yang coba dinilainya. Sebuah esai tidak hanya sekedar menunjukkan fakta atau menceritakan sebuah pengalaman; ia menyelipkan opini penulis di antara fakta-fakta dan pengalaman 
tersebut. Secara umum, struktur esai dibagi menjadi tiga bagian: pendahuluan, isi, dan penutup. Pendahuluan berisi latar blakang informasi yang mengidentifikasi subjek bahasan dan pengantar tentang subjek yang akan dinilai oleh si penulis tersebut. Isi atau tubuh esai menyajikan seluruh informasi tentang subyek. Penutup atau bagian akhir memberikan kesimpulan dengan menyebutkan kembali ide pokok, ringkasan dari tubuh esai, atau menambahkan beberapa observasi tentang subyek yang dinilai oleh si penulis.

Sikap dan kemampuan berpikir kritik perlu dikembangkan dalam kegiatan pembelajaran di sekolah. Proses pembelajaran yang dapat mengembangkan keterampilan berpikir kritis adalah yang mendorong siswa untuk berdiskusi, mengemukakan pendapat gagasannya secara lisan dan tertulis, serta mengkaji dan menemukan pengetahuan. Siswa dapat mengembangkan potensi yang dimiliki dan memperoleh pengetahuan yang baik dan bermanfaat dengan meresensi atau mengkritik buku. Melalui kegiatan meresensi berpikir kritis serta terbuka akan kritik.

Berdasarkan analisis penelitian terhadap teks resensi yang diperoleh kesimpulan bahwa di dalam teks resensi terdapat ragam bahasa kritik dan kalimat efektif yang digunakan siswa. Ragam bahasa kritik dan kalimat efektif tersebut merupakan ragam bahasa yang dipakai siswa dalam kegiatan mengkritik atau menilai karya konkret, yaitu buku karya sastra yang di bacanya. Kritik siswa terhadap buku tersebut yang dibacanya adalah penilaian obyektif terhadap kelebihan dan kekurangan buku tersebut. Hal ini sesuai dengan pendapat Keraf (1994, hlm. 279) yang menyatakan bahwa meresensi buku dapat berarti memberikan penilaian atau mengkritik buku. Sementara mengkritik berarti menilai dan menunjukkan kelebihan-kelebihan dan kekurangan-kekurangan buku.

Bahasa kritik siswa pada tulisan teks resensi buku berisi argument siswa tentang evaluasi atau penilaiannya terhadap kelebihan dan kekurangan buku. Argument tersebut dinyatakan oleh siswa secara jelas dan masuk akal. Kejelasan argument siswa terlihat dari informasi keunggulan dan kelebihan buku yangdiberikan. Hal ini sesuai mendapat Al Wasilah (2007, hlm.45) bahwa kritik yang baik secara bernalar menghargai kelebihan, menunjukkan kelemahan, dan mengajukan alternative pemikiran atau solusi. Namun, dalam hal ini bahasa kritik yang digunakan siswa belum sampai pada tarap memberikan alternative pemikiran atau solusi.

Informasi keunggulan dan kelemahan buku yang dikemukakan siswa dalam bahasa kritiknya meliputi penilaian terhadap unsur karya sastra, penilaian fisik buku, penilaian pada isi buku, dan penilaian terhadap bahasa yang digunakan dalam buku yang diresensinya penilaian terhadap unsur karya sastra yaitu pada unsur penokohan, alur, latar, amanat, dan konflik. Penilaian fisik buku yaitu mengenai gambar, tulisan, warna, dan cover. Penilaian pada isi buku yaitu tentang keunikan cerita, pelajaran hidup, dan nilai-nilai kehidupan. Penilaian terhadap bahasa yaitu seputar kalimat yang tidak mudah dipahami, pengulangan kalimat, dan bahasa yang tidak serius tapi tetap sopan.

Argument yang dikemukakan dalam bahasa kritik siswa didukung dengan bukti-bukti atau fakta yang menguatkan. Data factual atau fakta empiris sebagai 
pendukung terdapat dalam semua bahasa kritik siswa yang peneliti analisis. Bukti atau fakta pendukung tersebut sesuai dengan argument yang disampaikan siswa mengenai kelebihan dan kekurangan buku. Sebagaimana pendapat Emi Emilia (2010, hlm.4) bahwa cara untuk mengukur seberapa baik keterampilan berpikir kritis dilakukan meliputi kejelasan dalam argument, relevansi data dan bukti yang digunakan untuk mendukung argument.

Kata-kata yang emnjadi indicator bahasa kritk terdapat bahasa kritik yang digunakan siswa dalam teks resensi yang ditulisnya. Kata-kata yang menjadi indicator bahasa kritik yang terdapat dalam tulisan siswa, yaitu karena dan sehingga. Hal ini senada dengan pendapat Fisher (2009, hlm. 21-27) bahwa keterampilan berpikir kritis jika dipraktikkan, yaitu dengan cara memberikan kesimpulan dan argument. Jenis bahasa yang secara khusus dipakai adalah katakata dan frase-frase tertentu untuk menunjukkan argument atau sebuah kesimpulan. Kata-kata yang menjadi indicator-indikator argument atau kesimpulan tersebut diantaranya adalah karena, sehingga, oleh karena itu, jadi, karenanya, seharusnya. Namun, kata-kata yang menjadi indicator bahasa kritik tersebut tidak terdapat dalam semua bahasa kritik siswa yang peneliti analisis.

Dari informasi kuantitatif teori tersebut maka peneliti mempunayi kesimpulan bahwa terdapat pengaruh yang signifikan penguasaan ragam bahasa kritik dan kalimat efektif secara bersama-sama terhadap pembelajaran menulis teks resensi.

\section{Pengaruh penguasaan ragam bahasa kritik terhadap pembelajaran menulis teks resensi.}

Dari pengujian hipotesis diperolah bahwa nilai $\mathbf{S i g}=0,002$ dan $\mathbf{t}_{\text {hitung }}=$ 2,901 sedangkan $t_{\text {tabel }}=1,67$. Dikarenakan nilai Sig $<0,05$ dan $t_{\text {hitung }}>t_{\text {tabel }}$ maka $\mathrm{H}_{0}$ ditolak yang berarti terdapat pengaruh yang signifikan variabel $\mathrm{X}_{1}$ (penguasaan ragam bahasa kritik) terdapat variabel terikat $\mathrm{Y}$ (pembelajaran menulis teks resensi)

Menurut sintesis teori yang ada di Bab II, bahasa digunakan salah satunya untuk tujuan berkomunikasi. Tujuan komunikasi adalah untuk menyampaikan pesan dan menjalin hubungan sosial. Penyampaian pesan tersebut dapat dilakukan secara lisan maupun tulisan. Tujuan komunikasi untuk menjalani hubungan dilakukan dengan menggunakan beberapa strategi. Misalnya, dengan menggunakan ungkapan kesopanan.

Kesantunan berbahasa merupakan piranti penting untuk membentuk tuturan bahasa Indonesia yang efektif strategi pembentukkan dan penggunaan kesatuan berbahasa perlu dikuasai oleh setiap penutur bahasa Indonesia. Strategi tersebut diantaranya meliputi ragam kesantunan berbahasa dan strategi berbahasa yang santun. Ragam kesantunan salah satunya meliputi ragam kesantunan mengkritik.

Dari analisis ditemukan bahwa bahasa kritik dalam teks resensi yang ditulis siswa ditinjau dari nilai rasa pilihan kata yang digunakannya ada yang susah menemuhi penggunaan piliha kata yang mengandung nilai rasa halus dan sopan dan ada juga yang belum. Bahasa kritik yang menggunakan pilihan kata yang menggunakan nilai rasa halus atau sopan berarti bahasa kritik tersebut sudah 
santun bahasa kritik yang menggunakan pilihan kata yang tidak mengandung nilai rasa halus atau sopan berarti bahasa kritik tersebut belum atau tidak santun.

Pilihan kata dalam bahasa kritik siswa yang tidak mengandung nilai rasa halus atau sopan tersebut diantaranya terlalu banyak, tidak sesuai, tidak jelas, terlalu besar. Pilihan kata dalam bahasa kritik siswa yang sudah mengandung nilai rasa halus atau sopan berupa kurang dipahami, kurang menarik, kurang detail, kurang terkesan, kurang menambahkan, sedikit konflik, sedikit membingungkan, agak susah untuk dibaca. Hal ini sesuai prinsip kesantunan Pranowo yang menekankan pada penggunaan pilihan kata yang mengandung nilai rasa halus atau ungkapan kesopanan.

Bahasa kritik yang memenuhi kaidah berbahasa yang santun adalah bahasa kritik yang menggunakan pilihan kata yang memiliki nilai rasa, halus atau sopan, serta tidak merugikan orang lain atau memberikan keuntungan bagi orang lain. Kesantunan bahasa kritik siswa dapat dilihat berdasarkan penggunaan pilihan kata yang mengandung nilai rasa, ungkapan, dan gaya bahasa yang halus atau sopan, serta tidak merugikan orang lain atau memberikan keuntungan bagi orang lain.

Dari hasil analisis dapat disimpulkan bahwa bahasa kritik pada teks resensi buku yang ditulis siswa ada yang sudah memenuhi kaidah kesantunan berbahasa dan ada juga yang tidak memenuhi kaidah berbahasa yang santun. Bahasa kritik yang peneliti temukan terhadap teks resensi yang di tulis siswa tidak seluruhnya menggunakan pilihan kata yang mengandung nilai rasa halus atau sopan dan tidak merugikan orang lain.

Dari informasi kuantitatif teori tersebut maka peneliti berkesimpulan bahwa terdapat pengaruh yang signifikan penguasaan ragam bahasa kritik terhadap pembelajaran menulis teks resensi.

\section{Pengaruh penguasaan kalimat efektif terhadap pembelajaran menulis teks resensi.}

Dari pengujian hipotesis diperolah bahwa nilai Sig $=0,000$ dan $\mathbf{t}_{\text {hitung }}=$ 4,877 sedangkan $t_{\text {tabel }}=1,67$. Dikarenakan nilai Sig $<0,05$ dan $t_{\text {hitung }}>t_{\text {tabel }}$ maka $\mathrm{H}_{0}$ ditolak yang berarti terdapat pengaruh yang signifikan variabel $\mathrm{X}_{2}$ (penguasaan kalimat efektif) terdapat variabel terikat Y (pembelajaran menulis teks resensi)

Menurut sintesis teori yang ada di Bab II, pembelajaran dalam hal ini siswa memerlukan strategi dalam proses belajar bahasa. Strategi tersebut dapat membuat siswa menjadi lebih leluasa dalam berpikir dan mengembangkan kemampuan kognitifnya secara lebih mendalam dengan menggunakan bahasa yang baik dan benar. Hal ini sesuai dengan pendapat Iskandarwassid dan Sunendar (2013, hlm. 3) yang menjelaskan bahwa strategi pembelajar dalam proses belajar bahasa membuat siswa dapat lebih leluasa dalam berpikir dan mengembangkan kemampuan kognitifnya secara lebih mendalam dengan menggunakan bahasa yang baik dan benar.

Bahasa kritik yang digunakan siswa tidak hanya harus memperhatikan bahasa yang baik atau santun tetapi juga benar. Bahasa yang benar dan jelas akan dengan mudah dipahami orang lain secara tepat. Agar kalimat atau bahasa yang ditulis dapat member informasi kepada pembaca secara tepat diperlukan kalimat 
yang efektif. Hal ini senada dengan pendapat Widjono (2012, hlm. 205) yang mengatakan bahwa kalimat efektif adalah kalimat yang singkat, padat, jelas, lengkap, dan dapat menyampaikan informasi secara tepat.

Kalimat efektif adalah kalimat yang dapat mengungkapkan gagasan penutur atau penulis secara tepat sehingga dapat dipahami oleh pendengar atau pembaca secara tepat. Kalimat efektif dapat mengomunikasikan pikiran atau perasaan penulis atau pembicara kepada pembaca atau pendengar secara tepat. Sebagaimana pernyataan Keraf (1994, hlm. 36) bahwa kalimat efektif adalah kalimat yang secara tepat dapat mewakili gagasan atau perasaan pembicara atau penulis; sanggup menimbulkan gagasan yang sama tepatnya dalam pikiran pendengar atau pembaca seperti yang dipikirkan oleh pembicara atau penulis.

Kalimat efektif dapat mewakili pikiran penulis atau pembicara secara tepat sehingga pendengar atau pembaca dapat memahami pikiran tersebut dengan mudah, jelas, dan lengkap. Sebuah kalimat dapat dikatakan efektif apabila sebuah kalimat dalam bahasa tulis dapat dipahami pembaca karena kalimat itu disampaikan tanpa meninggalkan aturan ketatabahasaan yang benar, keefektifan kalimat atau bahasa kritik siswa dapat dilihat berdasarkan kesantunan dan kepaduan, kesejajaran, kehematan, kelogisan, ketepatan diksi dan ejaan. Seperti halnya pendapat Mahayana (2015, hlm. 111) bahwa sebuah kalimat dapat dikatakan efektif apabila sebuah kalimat dalam bahasa tulis dapat dipahami pembaca karena kalimat itu disampaikan tanpa meninggalkan aturan ketatabahasaan yang benar.

Berdasarkan analisis yang telah peneliti lakukan, maka diperolah kesimpulan bahwa kalimat efektif dalam bahasa kritik yang digunakan siswa dalam teks resensi masih terdapat kalimat efektif dalam bahasa kritik yang tidak memenuhi kaidah keefektifan kalimat. Bahasa kritik siswa yang efektif maupun tidak efektif dapat dilihat pada unsur kesantunan gagasan dan kepaduan antar unsur kalimat, kehematan atau menghindari penggunaan kata yang tidak perlu, kesejajaran atau kesamaan bentuk bahasa yang digunakan, gagasan kalimat logis atau masuk akal, ketepatan pilihan kata, dan penggunaan ejaan yang sesuai.

Sebagaimana pendapat Finoza $(2005,147-152)$ bahwa kalimat efektif harus memenuhi kriteria (1) kesatuan, terdapatnya ide pokok dalam sebuah kalimat (2) kepaduan (koherensi), terjadi hubungan yang padu antara unsur-unsur pembentuk kalimat, (3) keparalelan atau kesejajaran, terdapat unsur-unsur yang sama derajatnya, sama pola atau susunan kata dan frasa yang dipakai di dalam kalimat, (4) ketepatan, yakni kesesuaian atau kecocokan pemakaian unsur-unsur yang membangun suatu kalimat sehingga terbentuk pengertian yang bulat dan pasti, (5) kehematan, adanya upaya menghindari pemakaian kata yang tidak perlu.

Hasil analisis terhadap teks resensi yang ditulis siswa diperoleh bahasa kritik yang tidak seluruhnya memenuhi kaidah keefektifan kalimat. Dalam teks resensi yang ditulis siswa terdapat bahasa kritik yang efektif dan tidak efektif. Bahasa kritik yang tidak memenuhi kaidah keefektifan kalimat lebih banyak jika dibandingkan bahasa kritik siswa yang sudah memenuhi kaidah kalimat efektif.

Ketidakefektifan kalimat yang disebabkan oleh ketidaktepatan pilihan kata atau diksi adalah yang paling banyak. Urutan ketidakefektifan kalimat berikutnya adalah karena ketidaksatuan gagasan dan ketidakpaduan antar unsur kalimat. 
Selanjutnya diikuti ketidakefektifan karena ketidakhematan atau pemakaian kata yang tidak perlu. Terakhir ketidakefektifan kalimat karena ketidaksejajaran bentuk bahasa.

Dari informasi kuantitatif dan teori tersebut maka peneliti berkesimpulan bahwa terdapat pengaruh yang signifikan penguasaan kalimat efektif terhadap pembelajaran menulis teks resensi.

\section{SIMPULAN}

Berdasarkan deskripsi data penelitian dan setelah dilakukan analisis maka dapat disimpulkan :

1. Terdapat pengaruh yang signifikan penguasaan ragam bahasa kritik dan kalimat efektif secara bersama-sama terhadap pembelajaran menulis teks resensi siswa SMK Swasta Kota Bekasi. Hal ini dibuktikan dengan nilai Sig $=0.000<0,05$ dan Fhitung $=49,431$.

2. Terdapat pengaruh yang signifikan penguasaan ragam bahasa kritik terhadap pembelajaran menulis teks resensi siswa SMK Swasta di Kota Bekasi. Hal ini dibuktikan dengan nilai Sig $=0.002<0,05$ dan thitung $=2$, 901.

3. Terdapat pengaruh yang signifikan penguasaan kalimat efektif terhadap pembelajaran menulis teks resensi siswa SMK Swasta di Kota Bekasi. Hal ini dibuktikan dengan nilai Sig $=0.000<0,05$ dan thitung $=4,877$

\section{DAFTAR PUSTAKA}

Ahmad, S. R.,\& Hendri, P. (2015). Mudah menguasai Bahasa Indonesia. Bandung: Yrama Widya.

Alwasilah, A. C. (2011). Linguistik suatu pengantar. Bandung: Angkasa.

Chaer, A. (2010). Kesantunan berbahasa. Jakarta: Rineka Cipta

Chaer, A. dan Agustina, L. (1995). Sosiolinguistik. Jakarta: Rineka Cipta.

Finoza, L. (2005). Komposisi bahasa Indonesia. Jakarta: Diksi Insan Mulia.

Fisher, A. (2009). Berpikir kritis: sebuah pengantar. Jakarta: Erlangga.

Keraf, G. (1994)). Komposisi. Ende Flores: Nusa Indah.

Pranowo. 2012. Berbahasa secara santun. Yogyakarta: Pustaka Pelajar.

Samad, D. (1997). Dasar-dasar meresensi buku. Jakarta: Grasindo.

Santoso, A. (2012). Studi bahasa kritis. Bandung: Mandar Maju.

Semi, A. (2013). Kritik sastra. Bandung: Angkasa.

Suriasumantri. (2007). Filsafat ilmu. Jakarta: Pustaka Sinar Harapan.

Tilaar, H.A.R. (2011). Pedagogik kritis. Jakarta: Rineka Cipta.

Tilaar, H.A.R. (2015). Pedagogik teoritis untuk Indonesia. Jakarta: Kompas.

Wijana, I. D. P. (2013). Sosiolinguistik. Yogyakarta: Pustaka Pelajar.

Zamroni., \& Mahfudz. (2009). Panduan teknis pembelajaran yang mengembangkan critical thinking. Jakarta: Depdiknas. 